ELS Journal on Interdisciplinary Studies on Humanities

Volume 2 Issue 3, 2019

ISSN (print) : 2621-0843

ISSN (online) : 2621-0835

Homepage : http://journal.unhas.ac.id/index.php/jish

\title{
Pragmatic Awareness of English Conversational Implicatures among Yemeni-Arabic EFL College Learners
}

\author{
Haifa Mohammad Ahmad Nassar ${ }^{1}$, Abdusalam M. Gh. Al-Ghrafy ${ }^{2}$ \\ ${ }^{1}$ haifaaama@gmail.com
}

\begin{abstract}
Conversational implicatures are considered as a tool of indirect communication. Through the researcher's teaching experience, it has been noticed that Yemeni-Arabic EFL college learners are not sufficiently aware of the rules of the use of English and that often words and expressions convey messages above and beyond their literal meanings. This study examined the perception of English conversational implicatures among those learners. The method applied in this study was empirical analytical-descriptive with a test and an interview. The subjects were 62 Yemeni-Arabic EFL college learners. A multiple-choice discourse completion test and an interview were used for collecting the study data. All the implicatures included in the test were taken from the study related literature, whereas most of the test scenarios containing these implicatures were ready-made ones that the researcher came across throughout her reading. The test contains seven types of conversational implicature: Overstatement, Deliberate Ambiguity, Assertion, Indirect Refusal, Disapproval, Indirect Criticism, and Indirect Request. The results showed that Yemeni-Arabic EFL college learners do face challenges in relation to the interpretation of these seven English conversational implicatures.
\end{abstract}

Keywords: Pragmatic Awareness, Conversational Implicatures, Speech Acts, EFL College Learners, Misunderstanding

How to cite: Nassar, H. \& Al-Ghrafy, A. (2019). Pragmatic Awareness of English Conversational Implicatures among Yemeni-Arabic EFL College Learners. ELS Journal on Interdisciplinary Studies in Humanities, 2 (3), 339 - 320

\section{Introduction}

In one model of pragmatic ability, pragmatic awareness can be characterized as comprehension of speech acts and conversational implicatures (Thomas, 2013). Meaning as one of the key concepts in pragmatics is one of the most controversial points that cause many problems in communication. This is because tracing the sense of a particular linguistic item sometimes does not only call upon linguistic knowledge but on pragmatic knowledge as well.

Austin's theory of speech acts and Grice's theory of speaker's meaning were both meant to provide the foundation for a theory of language, or at least for a theory of linguistic meaning (Recanati, 2006, p.443).

\footnotetext{
${ }^{1,2}$ Sana'a University, Yemen 
Speech acts are an important aspect of pragmatics and they can be distinguished with regard to their structure. Whenever there is a direct relationship between the function of a speech act and its structural form, we have a direct speech act. On the other hand, when there is no direct relationship between a structure and a form, but rather an indirect one, the speech act is considered indirect. Morgan (1978) and Gibbs (1983) state that some indirect speech acts operate as implicatures.

Grice (1975/1989) as the founder of the concept of 'implicature' deals with an explication of speaker's meaning in terms of intentions. He differentiates between what an utterance conventionally means and what it pragmatically means. He suggests that conversation is a characteristically purposeful and cooperative enterprise governed by what he calls the Cooperative Principle: "Make your conversational contribution such as is required, at the stage at which it occurs, by the accepted purpose or direction of the talk exchange in which you are engaged ( $p$. 26)". This principle together with its four maxims (quantity, quality, relevance, and manner) will be expected to be observed and obeyed by interlocutors in a talk exchange. Consequently, the principle generally assumes that conversation partners will be cooperative: informative, truthful, relevant, and succinct. Hence, if things are communicated, even though they are not clearly expressed, then a conversational implicature works.

A conversational implicature is a case in which a speaker produces a coded utterance to convey certain intent. The listener analyzes and interprets the communicative intention that has been revealed by the speaker. A speaker A, for example, says 'Will Sally be at the meeting?' and B says 'Her car broke down'. The intention is 'Sally will not be at the meeting'. Although native speakers intuit it smoothly, it becomes rather problematic for EFL learners.

More specifically, this research paper demonstrates that Yemeni-Arabic EFL college learners face difficulties in understanding conversational implicatures, which is critical in illuminating which types of implicature have comprehension difficulty more than the others.

\section{Statement of the Problem}

In most world countries including Yemen, English is a language that is used in a variety of settings where people need to interact, not only for basic interpersonal communication, but also in academic and business settings. However, through the researcher's teaching experience at EFL college settings, it was noticed that YemeniArabic learners encounter unsuccessful experiences to communicate using English language. They are not sufficiently aware of the rules of the use of English and that often words and expressions convey messages above and beyond their literal meanings. So, it is not surprising that errors are found as inevitable events in language learning process of their EFL communication. But, such failures, which refer to the inability to recognize what is meant by what is said, may also result in too many communication failures that pose an obstacle to cross-cultural communication.

Therefore, such difficulties and unsuccessful experiences are supposed to be studied and uncovered to minimize and reduce such communication breakdowns and help EFL college learners use English language appropriately. Thus, the current study is an attempt to identify such communication breakdowns in order to 
understand the reasons behind them and remedy them. The main concern of this study is to find out to what extent Yemeni-Arabic EFL college learners perceive different conversational implicatures. In other words, the study seeks to answer the question: To what extent do Yemeni-Arabic EFL college learners perceive various English conversational implicatures?

\section{Literature Review}

Language is an important part of people's everyday life as it is the tool to communicate between each other. Language thereby is used to transmit ideas, feelings, and thoughts. Leech (1983) argues "We cannot really understand the nature of language itself unless we understand pragmatics" (p.34). Thus, pragmatics is regarded.

\section{a. Theoretical Implications of Conversational Implicature}

The emergence of what is often called modern pragmatics today is mainly included under the two prominent theories: speech act theory and conversational implicature theory as referred by Mey (2009, p. 18). These are discussed in the following sections.

\section{A Theory of Speech Act}

John Austin (1962) is best known for one major contribution to contemporary philosophy: speech act theory, the idea that every use of language carries a performative dimension. According to him, there is quite often something which lies beyond the superficial contextless meaning of words, which will give us a more complete picture of meaning in language. He calls this performative utterance, which refers to some kind of action which is deemed to have been performed by saying something. "[Performative utterance] ... indicates that the issuing of the utterance is performing of an action" (Ibid, 1962, p.6). Performative utterance is contrasted to constative utterance, which is an act of providing information and it can be judged as either true or false, such as 'The cat is under the mat and the cat is on the mat'.

Speech acts can be also distinguished with regard to their structure. Whenever there is a direct relationship between the function of a speech act and its structural form, we have a direct speech act. On the other hand, when there is no direct relationship between a structure and a form, but rather an indirect one, the speech act is considered indirect.

Austin (1962) argued that "To determine what illocutionary act is so performed we must determine in what way are using the locution" (p.98). This means that what is said (the locutionary act) does not determine the illocutionary act(s) being performed. Thus, we can perform a speech act directly or indirectly, by way of performing another speech act. Searle (1979) states that an indirect speech act is one "performed by means of another" (p.60). That means that there is an indirect relationship between the form and the function of the utterance.

\section{Theory of Conversation}

Grice (1975/1989) proposes that participants in a communicative exchange are guided by a principle that determines the way in which language is used with maximum efficiency and effect to achieve rational communication. He calls this principle as the Cooperative Principle (CP), which states that make your 
conversational contribution such as is required, at the stage at which it occurs, by the accepted purpose or direction of the talk exchange in which you are engaged. This principle is an umbrella term for nine components that guide how we communicate. These nine components are grouped together into the four conversational categories or maxims of quality (truthfulness), quantity (informativeness), relation (relevance), and manner (perspicuity).

The CP aims at guiding participants on using language efficiently and effectively, and towards achieving cooperative goals. In other words, it assumes that people taking part in communication expect themselves and the others to be cooperative, that is, be truthful, be informative, be relevant and be brief. Implicatures are generated when the audience realizes that an assumption is incompatible with the speaker intending to communicate what was said by the utterance. The audience is led to look for some other content the speaker might intend to get across. This other content is the implicature.

\section{Methodology}

The study is both quantitative and qualitative since the students' wrong or right responses in misunderstanding each implicature in the study test are counted in numbers, whereas the participants' responses to the questions of the study interview are explained in words.

For the sake of reliability, the research test was shown to seven experts in the field to be checked. Expert judgments helped to include plausible and consistent scenarios.

Prior to conducting the study test, a pilot study was conducted on a group of $10 \%$ of the number of the study population to examine the techniques needed for administering the test and to investigate the possibilities of undertaking it in collecting the related data. The pilot study was conducted one week before administrating the test from which students who have participated in the pilot task were excluded.

The population of the study consisted of the fourth level students at the English Department, Faculty of Education- Sana'a University. 50\% of the study population was selected as the study sample on which the study test will be conducted. The purpose of deciding such percentage was to make the study sample representative of the study population. This was based upon the principle that a larger sample size would ensure the inclusion of subjects with diverse pragmatic backgrounds. The researcher selected the study sample using the simple random sampling technique. According to Brink (1996), Burns and Grove (2001), a random sampling ensures that all the participants have an equal chance to be selected and it avoids selection bias and thus typically reflects the characteristics of the population as a whole. Only $10 \%$ of this study sample participated in the study interview after conducting the study test.

After administrating the study test, an analysis for the subjects' responses was conducted to identify test items difficulty, using the Statistical Package for Social Sciences (SPSS) version 25. The difficulty of a test item is understood as the proportion of the subjects who answer a test item correctly. If this proportion is equal or higher than $50 \%$, the implicature is considered to be easy for them. On the other hand, if it is less than $50 \%$, the implicature is considered to be difficult for them. To 
calculate the difficulty of an item, the number of subjects who answered it correctly is divided by the total number of the subjects who answered it (incorrectly and correctly) multiplied by 100 . Usually this proportion is indicated by the letter pi, which denotes the difficulty of the item (Crocker and Algina, 1986). It is calculated by the following formula:

$$
\rho i=\frac{A}{N} \times 100
$$

Where:

$\rho i=$ Difficulty index of item i

$A=$ Number of correct answers to item $i$

$\mathrm{N}=$ Number of correct answers plus number of incorrect answers to item i

After the test was administered, the unstructured interviews were employed to have a clear vision of the subjects' performance, and to find out the potential sources of pragmatic failure that Yemeni-Arabic EFL college learners tend to produce.

\section{Findings}

This section presents the study findings. It first presents a summary of the difficult conversational implicatures according to the study test. Then, it presents discussion of interview questions and interpretation of the study results.

\section{a Difficult Implicatures According to the Study Test}

Generally speaking, data clearly showed that Yemeni-Arabic EFL college learners encounter challenges to a large extent in understanding English conversational implicatures. The difficulty of a test item is determined by the proportion of the subjects who answered it correctly. If this proportion is equal to or higher than $50 \%$, the implicature is considered to be easy for them. However, if it is less than $50 \%$, the implicature is considered to be difficult for them. Tables (1to 4) below indicate the difficulty levels of the test implicatures according to the 62 subjects' responses.

\begin{tabular}{|c|c|c|c|c|c|}
\hline $\begin{array}{l}\text { Scenario } 1 \\
\text { Type/Subtype }\end{array}$ & & & $\begin{array}{l}\text { Scenario } 2 \\
\text { Type/Subtype }\end{array}$ & & \\
\hline Particularized & \multirow[b]{2}{*}{$\begin{array}{l}\text { Level of } \\
\text { Difficulty }\end{array}$} & \multirow[b]{2}{*}{$\begin{array}{l}\text { Frequenc } \\
\mathrm{y}\end{array}$} & Particularized & \multirow{2}{*}{$\begin{array}{l}\text { Level } \\
\text { of } \\
\text { Difficult } \\
y\end{array}$} & \multirow[b]{2}{*}{$\begin{array}{l}\text { Frequenc } \\
\mathrm{y}\end{array}$} \\
\hline Overstatement & & & $\begin{array}{l}\text { Deliberate } \\
\text { Ambiguity }\end{array}$ & & \\
\hline $\begin{array}{l}\text { Incorrect } \\
\text { Responses }\end{array}$ & $82 \%$ & 51 & Incorrect Responses & $77 \%$ & 48 \\
\hline Correct Responses & $18 \%$ & 11 & Correct Responses & $23 \%$ & 14 \\
\hline Total & $100 \%$ & 62 & Total & $100 \%$ & 62 \\
\hline
\end{tabular}

Table 1. Test Scenarios $1 \& 2$

Table 1 provides the difficulty levels of the two particularized conversational implicatures included in scenarios 1 and 2 . It also shows the frequency of the in/correct responses of each of them. The difficulty coefficient was calculated to 
determine the level of difficulty of them. This shows the resulted differences in the students' responses to both scenarios of the test. This also means that these implicatures were not comprehended by the majority of the research subjects. The levels of difficulty of the two items are $18 \%$ and $23 \%$ respectively. This shows that these levels are very high and most of students cannot select the right alternative.

Table 2. Test Scenarios $3 \& 4$

\begin{tabular}{|c|c|c|c|c|c|}
\hline $\begin{array}{l}\text { Scenario } 3 \\
\text { Type/Subtype }\end{array}$ & & & $\begin{array}{l}\text { Scenario } 4 \\
\text { Type/Subtype }\end{array}$ & & \\
\hline Generalized & \multirow{2}{*}{$\begin{array}{l}\text { Level of } \\
\text { Difficulty }\end{array}$} & \multirow{2}{*}{$\begin{array}{l}\text { Frequenc } \\
\text { y }\end{array}$} & Particularized & \multirow{2}{*}{$\begin{array}{l}\text { Level } \\
\text { of } \\
\text { Difficult } \\
y\end{array}$} & \multirow[b]{2}{*}{$\begin{array}{l}\text { Frequenc } \\
y\end{array}$} \\
\hline Assertion & & & Indirect refusal & & \\
\hline Incorrect Response & $69 \%$ & 43 & Incorrect Response & $69 \%$ & 43 \\
\hline Correct Response & $31 \%$ & 19 & Correct Response & $31 \%$ & 19 \\
\hline Total & $100 \%$ & 62 & Total & $100 \%$ & 62 \\
\hline
\end{tabular}

As presented in Table 2 above, the generalized and particularized conversational implicatures included in scenarios 3 and 4 were also difficult for the students. Only 19 out of the 62 subjects selected the appropriate answer. The level of difficulty of both of them is $31 \%$ and this is considered to be a high level.

Table 3. Test Scenarios $5 \& 6$

\begin{tabular}{|c|c|c|c|c|c|}
\hline $\begin{array}{l}\text { Scenario } 5 \\
\text { Type/Subtype }\end{array}$ & & & $\begin{array}{l}\text { Scenario } 6 \\
\text { Type/Subtype }\end{array}$ & & \\
\hline Particularized & \multirow{2}{*}{$\begin{array}{l}\text { Level of } \\
\text { Difficulty }\end{array}$} & \multirow{2}{*}{$\begin{array}{l}\text { Frequenc } \\
\mathrm{y}\end{array}$} & Particularized & \multirow{2}{*}{$\begin{array}{l}\text { Level of } \\
\text { Difficulty }\end{array}$} & \multirow{2}{*}{$\begin{array}{l}\text { Frequenc } \\
y\end{array}$} \\
\hline Disapproval & & & Indirect Criticism & & \\
\hline $\begin{array}{l}\text { Incorrect } \\
\text { Response }\end{array}$ & $65 \%$ & 40 & $\begin{array}{l}\text { Incorrect } \\
\text { Response }\end{array}$ & $63 \%$ & 39 \\
\hline Correct Response & $35 \%$ & 22 & Correct Response & $37 \%$ & 23 \\
\hline Total & $100 \%$ & 62 & Total & $100 \%$ & 62 \\
\hline
\end{tabular}

As Table 3 shows, the two particularized implicatures were not identified by a majority of the students. The levels of difficulty of the two of them are $35 \%$ and $37 \%$, successively.

Table 4. Test Scenario 7

\begin{tabular}{lcc}
\hline & $\begin{array}{c}\text { Scenario 7 } \\
\text { Type/Subtype }\end{array}$ \\
\hline Particularized & Level of Difficulty & Frequency \\
\hline Indirect Request & & \\
\hline Incorrect Response & $57 \%$ & 35 \\
\hline Correct Response & $44 \%$ & 27 \\
\hline Total & $100 \%$ & 62 \\
\hline
\end{tabular}

As shown in Table 4 above, the respondents found it hard to understand the particularized implicature as its level of difficulty is $44 \%$. Many respondents could not interpret it.

The research subjects faced difficulties to comprehend both main kinds of generalized and particularized conversational implicatures. All subtypes of implicatures were misinterpreted by most of the respondents as well. Many students 
struggle with difficulty, but at the end the majority of them fail to choose the appropriate answers.

According to the study test results, Yemeni-Arabic EFL college learners had difficulties in comprehending conversational implicatures to a great extent. The results show high difficulty levels in perceiving both main types, generalized and particularized, of all study test implicatures. These results go in line with the results obtained by some studies in the field. For example, Bouton (1988) confirms that native speakers and non native learners with the same language proficiency and different $L 1$ backgrounds differed in their interpretation of implicatures.

\section{b. Discussion of Interview Question and Interpretation of Results}

In addition to what has been mentioned above, more interpretation and clarification were extracted from the interviewees to know more about problems and challenges of perceiving conversational implicatures. The interviewees were required to express themselves and talk about the difficulties and challenges they experienced in understanding the study test implicatures while having it. Results of this section were collected from the interview question: Why do you think scenario (No...) was challenging to or was difficult to understand? The question was asked to be acquainted with the difficulties in terms of the respondents' own understanding to each test scenario which has a high level of difficulty.

As the study test results reveal that all the test scenarios are difficult for the respondents. The implicatures' scenarios are listed from the most difficult to the least difficult one: i.e. overstatement, deliberate ambiguity, assertion, indirect refusal, disapproval, indirect criticism and indirect refusal. These scenarios will be discussed in the following subsections.

\section{Overstatement}

This scenario is included a particularized implicature because the speaker flouted the maxim of quality of the cooperative principle and forces the listener to infer the meaning according to the specific context, especially when she stated that she's quite fond of him. It is an overstatement or hyperbole. Here is a transcript of this test scenario:

This conversation is taken place between a boy and a girl: Jim and Kathy.

Jim: Do you love me?

Kathy: I probably don't need to say this, but I'm quite fond of you.

QUESTION: Which of the following says what Kathy meant?

a) Kathy does love Jim.

b) Kathy does not love Jim.

c) Kathy likes Jim very much.

d) Kathy loves Jim.

This implicature was the most difficult one for the subjects and the problem might come from misunderstanding the hedge "I probably don't need to say this" and how native speakers of English often use hedges. As hedges in English are signals 
which suggest comparatively low degree of certainty conveyed for several purposes. But, many of the subjects perceive the meaning of this hedge as confirmation that conveys the idea that Jim knows how much Kathy loves him. One respondent said that Kathy wanted to inform Jim that he knows how it is between them, so there is no reason to ask such question. Another one reported that the statement "I probably don't need to say this" assures Jim that Kathy does love him. Moreover, a subject stated that in similar Yemeni-Arabic context, a speaker replies the question by saying "Yes" or "No", but in this scenario the answer of the question is different. Therefore, many of the respondents chose the wrong alternatives since the meaning of "I probably don't need to say this" is not clear to them as it expresses the speaker's intention.

Some others understood the negative meaning of the hedge, but the clause "I'm quite fond of you" misled them. They presumed that when Kathy said "I'm quite fond of you", she assures Jim that she definitely loves him and this refutes the hedge. They focused on the second part of the statement and neglected the first part to get the meaning. It seems that distinguishing features in the speakers' conversational styles in different cultures can make misunderstanding. One respondent stated that the first part of the sentence "I probably don't need to say this" indicates that she doesn't love him. But because she says "I'm quite fond of you", this means that she loves him so much. Another subject said that she inferred from Kathy's utterance, "I probably don't need to say this", that Kathy is sick of Jim. But although they got the right meaning of the hedge, they fail to choose the right answer because the statement "I am quite fond of you" was comprehended by them as that Kathy informed Jim how much she loves him, but not as an exaggerating utterance. Halliday (1978) and Hyland (2000) reported that one major rhetorical feature, hedges appear to be problematic for ESL/EFL students as statements do not just communicate ideas, but they also convey the speaker's attitude to the readers.

It looks that Yemeni-Arabic conversational style in presenting overstatement is different from the English's. In Yemeni-Arabic talk exchange, people usually use the utterance "I probably don't need to say this" to confirm what follows it, but not to suggest low degree of certainty as in English. Tannen (1989) mentions that not only the differences in cultures but also differences in the speakers' conversational styles can lead to various subtle misunderstanding and misjudgments (p. 11). It was found that semantic misalignment in English and Yemeni-Arabic can interfere in interpreting conversational implicatures, as comprehended from the Yemeni-Arabic EFL college learners' reaction to the hedge, "I probably don't need to say this".

Hence, in this scenario Kathy implicates that she does not love Jim and "Yes" or "No" are the proper answers which are usually given by native speakers of English in similar situations. Nevertheless, most of the subjects did not interpret Kathy's utterance successfully and the majority of them chose the alternatives "Kathy likes Jim very much" or "Kathy does love Jim", which might be due to the cultural and stylistic conversational differences.

\section{Deliberate Ambiguity}

This is a particularized implicature in which the relevance maxim is flouted. It is a deliberate ambiguity. It is also a difficult implicature for the subjects. Here is a transcript of the test scenario of this implicature: 
You and your friend who is a native speaker of English are in a bookshop in London. You pick up a book from a display in the bookshop and ask your friend the following question.

You: Have you read "Long Walk to Freedom"?

Friend: I find autobiographies fascinating.

QUESTION: Which of the following says what the friend meant?

a) No, I haven't read it.

b) No, I have just read autobiographies.

c) Yes, but I prefer reading autobiographies to reading books.

d) Yes, I have read it.

In this scenario, most respondents selected the choice, "Yes, but I prefer reading autobiographies to reading books" because the word "autobiographies" occurred in the friend's answer. As a consequence, many of them assumed that mentioning such word in the friend's answer denotes that the speaker prefers reading autobiographies to reading books. One of the respondents said that she felt that talking about autobiographies means that the friend likes reading this kind of books more than other kinds.

Some others selected the alternative, "No, I haven't read it" because they had thought that the friend chose to speak indirectly to avoid the embarrassing question. That is, the friend actually did not read the book and kept coming up against that question. Therefore, s/he brought up a different topic, autobiographies, and talked about it. Many respondents reported that the speaker asked about "Long Walk to Freedom" and the other speaker talked about autobiographies which were not in the first speaker's question, and this might indicate that either the friend wanted to avoid embarrassment or s/he did not understand the question. A respondent said that the friend's utterance, "I find autobiographies fascinating" implied that $s /$ he did not read the book which was asked about, but s/he read a book about autobiographies. Another one said that it is difficult for me because I didn't know exactly if the interlocutor reads the book or not. She could not guess what beyond what was said.

However in English conversations, in asking about a book that a person has read, it is customary to offer an evaluation. If "Long Walk to Freedom" is an autobiography then, by saying that the friend finds autobiographies fascinating, the addressee could realize it as an evaluation of the book and her/his recognition that the book is autobiographical may come from reading it. These guesses relevantly link the friend's utterance to the interlocutor's question. It is only an implicature, however, which means it could be wrong: the friend would not be speaking contradictorily if s/he extended her/his utterance to cancel the implicature as follows "I find autobiographies fascinating, but I haven't read that one yet."

Here, the maxim of relation: 'make your contribution in accordance with the context', is flouted and compeers generally assume that their conversation partners will be cooperative: relevant. Consequently, it seemed difficult for the study respondents to get the appropriate interpretation of this implicature. Bouton's study 
(1994) supports this finding. He found that relevance implicatures, which are more "idiosyncratically dependent on the relationship-between a particular utterance and its specific context", are more difficult to teach and learn.

\section{Assertion}

This scenario contains a generalized implicature which is an assertion. "An assertion is a speech act in which something is claimed to hold ... it is made by means of uttering a sentence in the indicative mood" (Stanford, 2007). In other words, an assertion is a speech act whereby the speaker puts forward a proposition as true. The sentence-type of the linguistic expression is imperative and the performed act is asserting. The generalized implicature is obtained from the speaker's utterance directly. Here is a transcript of this scenario:

Talking to the pupils who are in the math class, the teacher says the following:

Teacher: Let me tell you that, obviously, the square root of a quarter is a half.

QUESTION: Which of the following says what the teacher meant?

a) I believe that the square root of a quarter is a half.

b) I don't believe that the square root of a quarter is a half.

c) I wonder whether the square root of a quarter is a half.

d) I cannot explain it any longer. The square root of a quarter is a half.

In this scenario, the study subjects got the meaning of the individual words, but the context was difficult for them. Consequently, again the problem could not be fixed. One respondent mentioned that she understood the single words, but the meaning was difficult. In addition, the word "obviously" played a role in hindering the appropriate interpretation, as most of the subjects selected the choice (d). They interpreted that "obviously" exists as a sign to indicate that the teacher could not add more information than what s/he had already explained. They assumed that the teacher wanted to say that s/he would no longer talk to the pupils. So, s/he said briefly that the square root of a quarter is a half. One respondent reported that she selected the choice (d) because of the word "obviously" which reveals the meaning above. Nevertheless, "obviously" is considered to be a device in performing an English assertion. Levinson (1983) claims that "a performative adverb like obviously...seems to be restricted to assertions" (p. 266).

Besides, Yemeni-Arabic EFL learners may have radically different conceptions of 'what is said' because the Arabic way to assert is different from English as no mutually accepted meanings are grounded. As emphasis style or assertion in Arabic is an utterance or structure attached to what comes before which is named as the confirmed or "the followed by" (Al-Hlawani, 2000). It is used to reinforce and strengthen the meaning of the confirmed. Hence, an Arabic speaker has defined certain vehicles to be used to make an assertion or emphasis, whereas in English a speaker has a belief and wants to communicate it, which motivates an asserted utterance 'any utterance'. This might be the reason behind misunderstanding this implicature. 
To conclude, many of the subjects have no previous experience to help them understand such test contexts. In addition, the Arabic and English ways in performing assertion are completely different that made the majority of the subjects misinterpret this implicature.

\section{Indirect Refusal}

It is a particularized implicature because the speaker flouted the quantity maxim of the cooperative principle as the amount of information was too little. The following transcript is of this scenario:

The following chat takes place between a man and a gatekeeper.

Man: Can anyone use this car park?

Gatekeeper: It's for customers of the supermarket.

QUESTION: Which of the following says what the gatekeeper meant?

a) No.

b) The customers of the supermarket own the park.

c) Yes.

d) The customers of the supermarket can use the park.

Many of the respondents chose (d). They assumed that the gatekeeper did not answer the question, rather than s/he explained to the man how parking took place there. So, most of them selected the choice (d) because of the gatekeeper's response, "It's for customers of the supermarket". They thought that s/he wanted to tell the man that if you are a customer, you can use the bark and if not, you cannot use it. They assumed that the gatekeeper told the man more information about parking there and he did not respond to the question. Moreover, they said "It's for customers of the supermarket" implied that only the customers of the supermarket can use it. Therefore, (d) is the appropriate choice.

Nevertheless, others got the idea that it was a question and there should be a Yes/No response. But, they selected the choice (c) because I think that they paid no attention to the meaning of "anyone" occurred in the man's question. They assumed that the man was one of the customers and the appropriate answer should be (c). Actually, the gatekeeper's response is considered to be a polite answer, however saying "No" is considered as a rude response. This implicature is concerned with the English culture. Some researchers such as Keenan (1997) and Murray (2011) claim that learners' misinterpretations are due to the differences of cultural background.

\section{Disapproval}

It is a particularized implicature because the speaker flouted the manner maxim of the cooperative principle and forced the listener to infer the meaning according to the specific context. Here is a transcript of this scenario:

Tim and Paul are having the following chat about their flat mates, Ruth and John.

Tim: Ruth helped John far more than I expected. 
Paul: This may be a bit tedious, but the corner of John's lips turned slightly upwards.

QUESTION: Which of the following says what Paul meant?
a) John was very happy.
b) John did not exactly smile.
c) John was smiling.
d) John was angry with his friend.

This implicature was difficult to understand and this difficulty arose from not comprehending the context as a whole and also ignoring the hedge. I think that the respondents were interested in understanding the clause, "but the corner of John's lips turned slightly upwards". They focused on understanding the meaning of "upwards" that means "moving toward a high position", so they selected the alternative (c), "John was smiling". They informed the researcher that John did not laugh but he just smiled. Also, some of them chose the alternative (a), "John was very happy" and justified their choice that he was smiling, so he should be very happy with the help offered to him.

By contrast other participants chose (d) and justified their choice that John was not satisfied with his friend's help, so he should be angry with him. The participants neither understood the hedge, "this may be a bit tedious" nor the negative meaning of the word "slightly". As a result, the majority of them selected the wrong alternative. This implicature may be failed to go through by the study respondents, since most of them were successful in perceiving the context partially. Some words in the context such as 'slightly' also played a role in misinterpreting this implicature.

\section{Indirect Criticism}

This is a particularized implicature relating to the quality maxim of the cooperative principle. It is indirect criticism. Here is a transcript of this scenario:

You invited your friend who is a native speaker of English in. Now you and he are at your new flat and the following conversation starts:

You: Jim, do you like my new carpet?

Friend: The wallpaper's not bad.

QUESTION: Which of the following says what the Friend meant?

a) He likes both the wallpaper and the carpet.

b) He does not care about the appearance of the carpet. What is important to him is the wallpaper.

c) He does not like the carpet.

d) $\mathrm{He}$ is amazed by how nice the wallpaper is.

Many respondents had difficulty to decode the message constructed by the conversation interlocutors since the topic of the conversation is changed by the addressee. They reported that it was hard for them to get the meaning when one speaker was asking about a certain thing, and then the other is responding talking 
about a different topic. This made them confused and failed to select the best alternative. They also added that the words of the conversation were easy to understand, but interpreting the message was challenging to them. Many of them chose (b) "He does not care about the appearance of the carpet. What is important to him is the wallpaper" because they felt that the addressee was interested in the wallpaper, so s/he talked about it. This result goes in line with the study of Pratama, Nurkamto, Rustono and Marmant (2017). Their study results revealed that indirect criticism implicatures are the most problematic implicatures for all groups of the respondents. It is also consistent with Tannen (1989) research's results. According to Tannen, "Indirectness ... etc. can lead to pragmatic misunderstanding" (p. 23).

\section{Indirect Request}

It is a generalized implicature which is a speech act. The sentence type is declarative and the act is requesting. The following is the transcript of this scenario:

On a country walk, this conversation is taken place between two companions, Tim and Kate, while they are climbing a barbed wire fence.

Kate: Tim, my skirt is caught on the barbed wire.

QUESTION: Which of the following says what Kate meant?

a) Please, look at what happened to me.

b) That's why I don't like climbing fences.

c) It is harmful to climb a barbed wire fence.

d) Please, help me.

Many subjects selected (b) and (c). As they reported that they felt that Tim was reproved for bringing Kate there. Kate's utterance indicated that she was annoyed with Tim because of catching on the barbed. They said that saying such utterance denotes that Time took responsibility for what had happened to her recently. Consequently, they selected (b) or (c) to provide this interpretation. They misunderstood Kate's intention as a reproving may have inappropriately transferred from their Yemeni-Arabic norm to English.

This result gets along with the study result conducted by Wolfson (1989). He states that an important reason causing pragmatic misunderstanding is that English learners' pragmatic knowledge in their native language significantly influences their comprehension and production of pragmatic performance in English. Negative pragmatic transfer involves utilizing the sociolinguistic rules of speaking in one's native speech community when interacting within the target speech community ( $p$. 54).

\section{Conclusion}

Based on the seven scenarios of the study test and interviewees' views, the research results showed that Yemeni-Arabic EFL college learners did encounter difficulties to a great extent in understanding both generalized and particularized conversational implicatures: the seven test subtypes of implicatures: overstatement, deliberate ambiguity, assertion, indirect refusal, disapproval, indirect criticism and indirect request involving the four Gricean maxims of quantity, quality, relevance, and manner. 
The problems of misunderstanding conversational implicatures in English conversations comprehended by Yemeni-Arabic EFL college learners were analyzed and discussed. In the analysis of the scenarios, the researcher used the analyticaldescriptive method: the test implicatures' difficulty levels, the knowledge presented by the interviewees about their difficulties, the analysis of sociocultural differences between Yemeni-Arabic and English, and the Yemeni-Arabic background knowledge. The differences of English and Yemeni-Arabic in sociocultural background, conversational styles, speakers' conversational styles, semantic misalignment in interference, the indirectness, and the Yemeni-Arabic EFL college learners limited pragmatic knowledge and cultural information about English-speaking countries, have proved to be relevant factors which have caused misinterpretation of conversational implicatures among these learners.

Thus, with the analysis of the implicature test scenarios through determining the conversational implicatures which have high levels of difficulty and through the respondents' point of views, the study has investigated the extent to which YemeniArabic EFL college learners comprehend various English conversational implicatures. The indirectness and differences in sociocultural knowledge are instrumental in the misinterpretation of conversational contexts in the study. This study was restricted to 62 Yemeni-Arabic EFL college learners and a corpus of the generalized, particularized, and the subtypes of the particularized implicatures according to Grice's maxims of conversation and conversational implicature.

Based on the study results, EFL college leaners, in general, and Yemeni-Arabic EFL college learners, in particular, are recommended to be taught and given enough practice in how to understand and produce English conversational implicatures. The topic of conversational implicature is highly recommended to be included as one of the teaching components in one of the EFL college courses, in the upper levels in particular.

In further future studies investigating conversational implicatures, it is suggested by the study that research might be extended beyond just understanding English conversational implicatures. It would be preferred if expanded to include studies on writing English conversational implicatures or comparing English conversational implicatures with Yemeni-Arabic ones to gain a deeper understanding of the complex components of communication interaction.

\section{References}

Al-Hlawani, M.(2000). "Al-Wadheh-Fee- A-Nahwa".( 6th ed.)."Dar- Alma'amoonLitorath", 343-343.

Austin, J. (1962). How to Do Things with Words. London: Oxford University Press.

Bouton, L. F. (1988). A cross-cultural study of ability to interpret implicatures in English. World Englishes, 7, 183-196.

Bouton, L. F. (1994). Can NNS skill in interpreting implicature in American English be improved through explicit instruction? a pilot study. Pragmatics and Language Learning, 5, 89-109.

Brink, H. (1996). Fundamentals of research methodology for health care professional. Kenwyn: Juta. 
Burns, N. \& Grove, S. (2001). The practice of nursing research: conduct, critique and utilization. Philadelphia, Pennsylvania: W.B.Saunders.

Crocker, L. \& Algina, J. (1986). Introduction to classical and modern test theory. New York: Holt, Rinehart and Winston.

Depraetere \& R. Salkie (Eds.), Semantics and Pragmatics: Drawing a Line. (Pt. 2, pp. 55-73). Liverpool: Springer International Publishing Switzerland.

Dynel, M. (2013). Irony from a neo-Gricean perspective: on untruthfulness and evaluative implicature. Intercultural pragmatics, 10: 403-43. Retrieved from http://www.research gate.net/publication/269334568

Gibbs, R. (1983). Do people always process the literal meanings of indirect requests? Journal of Experimental Psychology: Learning, Memory, and Cognition, 9, 524-533.

Grice, H. P. (1975). Logic and Conversation. In P. Cole and J. Morgan (Eds.), Syntax and Semantics, vol. 3 (pp.41-58).New York: Academic Press.

Grice, H.P. (1989). Studies in the Way of Words. Harvard University Press.

Halliday, M. A. (1978). Language as Social Semiotic: The Social Interpretation of Language and Meaning. London: Edward Arnold.

Hyland, K. (1998). Exploring corporate rhetoric: Meta-discourse in CEOs letter. The Journal of Business Communication 35, 224-245.

Keenan, Elinor O. (1976). The universality of conversational postulates. Language in Society, 5, 67-80.

Leech, G. (1983). Principles of pragmatics. London: Longman.

Levinson, S. (1983). Pragmatics. Cambridge: Cambridge University Press.

Li, R., Rozina, R. \& Sazalie, A. (2015). An investigation into Chinese EFL learners' pragmatic competence. GEMA Online $\AA$ Journal of Language Studies. Vol. 15(2), 101-118.

Mey, J. (2009). Concise Encyclopedia of Pragmatics. (2nd ed.). Langford Lane, Kidlington, Oxford: Elsevier Ltd.

Morgan, J. (978). Two types of convention in indirect speech acts. In P. Cole (ed.), Syntax and semantics Vol. 9: Pragmatics. (pp. 261-280). New York: Academic Press.

Murray, J. C. (2011).Do bears fly? Revisiting conversational implicature in instructional pragmatics. TESL-EJ, $15(2)$. Retrieved from http://www.tesl. ej. org /word-press/ issues/volume 15/ej58/ej58a4/ >(September 13, 2013).

Pratama, H., Nurkamto, J., \& Rustono. (2017). Second Language Learners' Comprehension of Conversational Implicatures in English. The Southeast Asian Journal of English Language Studies - Vol. 23(3): 50 - 66.

Recanati, F. (2006). Pragmatics and Semantics. In L. Horn \& G. Ward (Eds.), Handbook of Pragmatics. (pp. 442-462). Oxford: Blackwell.

Searle, J. (1979). Expression and Meanings: Studies in the Theory of Speech Acts. New York: Cambridge University Press. 
Stanford Encyclopedia of Philosophy (2007). (Wed Dec 31, 2014 ed.). Retrieved from http: //www. plato.stanford.edu/entries / assertion/

Tannen, D. (1989). Talking Voices: Repetition, Dialogue, and Imagery in conversational Discourse. Cambridge England; New York: Cambridge University Press.

Thomas, J. (2013). Meaning in interaction: An introduction to pragmatics. New York : Routledge.

Wolfson, N. (1989). Perspectives: Sociolinguistics and TESOL Rowley. MA: Newbury House. 